\title{
Factors in Failure of Achieving LBI KPI: Teachers' Perception
}

\author{
Nithia Prathiba',2, Melor Md Yunus ${ }^{2}$ \\ ${ }^{1}$ SK (Felda) Jengka 23, Temerloh, Malaysia \\ ${ }^{2}$ Faculty of Education, Universiti Kebangsaan Malaysia (UKM), Bandar Baru Bangi, Malaysia \\ Email: nithiathevar@gmail.com, melor@ukm.edu.my
}

How to cite this paper: Prathiba, N., \& Yunus, M. M. (2019). Factors in Failure of Achieving LBI KPI: Teachers' Perception. Creative Education, 10, 621-636. https://doi.org/10.4236/ce.2019.103045

Received: February 23, 2019

Accepted: March 26, 2019

Published: March 29, 2019

Copyright () 2019 by author(s) and Scientific Research Publishing Inc. This work is licensed under the Creative Commons Attribution International License (CC BY 4.0).

http://creativecommons.org/licenses/by/4.0/

(c) (i) Open Access

\begin{abstract}
The Literacy, Numeracy and screening (LINUS LBI) 2.0, an intervention program was first implemented in 2013. It aimed to enhance the rate of English literacy among lower primary ESL learners. However, the number of non-achievers increased every year. The effectiveness of this program depends largely on the teachers, as they play a significant role in implementation. To a noteworthy extent, the teachers' perception which covers the factors leads to the failure of this program will realize the dream of Ministry of Education. Thus, this study was embarked to investigate teacher's perceptions on failure in achieving LBI KPI in grade B national schools in Temerloh District. A mixed method study was adopted to carry out this research with 80 teachers from 36 grade B national schools in Temerloh district. The participants were questioned on unavailability of resources, lack of training and support and other contributing factors. Questionnaire and individual interview were used to gather data. The overall findings of the study were that unavailability of resources and facilities, lack of training and support, pupils' attendance, cooperation of stakeholders and pedagogical knowledge played a huge role in the failure in achievement of LBI KPI. The implication of the study is that Ministry needs to be made aware of these factors in order to reevaluate the program to be successfully implemented and to take into considerations of the factors for other programs implementation as well.
\end{abstract}

\section{Keywords}

LINUS (LBI), Literacy Intervention Programme, KPI, Primary Level Pupils, Teachers' Perception

\section{Introduction}

UNESCO has defined literacy as ability to identify, understand, interpret, design, 
communicate, and learn to use printed and written materials relating to a variety of contexts (UNESCO, 2004). Basic concepts of literacy, which are to be able to communicate via text and printing, are embodied in the goals and focus of each educational system in the world. To conclude, literacy skills are integral part of any education system. Similar scenario occurs in our country too. In Malaysia, for instance, one crucial literacy skill that needs to be acquired as early as in the primary years of schooling is the English Language Literacy skills. This is because English is spoken and used as a second language (L2) in Malaysia as it is widely used (Thirusanku \& Melor, 2014). This is stipulated in the Malaysian Education Policy whereby English is taught as a compulsory subject since primary one in all Malaysian public schools (Rahman, 2014).

The issue of how to improve the standard of English proficiency among young learners has been one of the most discussed issues in Malaysia. To address this problem, a Literacy Intervention Program specifically for English, (LBI) program was introduced by the Malaysian Ministry of Education, in all lower primary schools nationwide since the beginning of 2013. LINUS is the acronym which stands for LI (Literacy), NU (Numeration) and S (Screening). This literacy program is targeted at pupils who are encountering problems in $3 \mathrm{M}$ which are reading, writing and counting. In the year of 2013, the LINUS program was relaunched as LINUS 2.0. LINUS 2.0 involves literacy screening for English Language, as contrasting to previous screening which focused only on Malay Language and Numeracy literacy. This initiative, which is an extension of the LINUS (Literacy, Numeracy and Screening) program for the Malay language and Mathematics subjects aims at enhancing the rate of literacy in English Language among the lower primary learners. The program contains 12 constructs that all pupils must master within 3 years. They must be prime-master the whole set of constructs. The success and failure of achievement is determined by the KPI. KPI is also known as the Key Performance Indicator. These are the indicators of progress toward the intended result. KPI includes setting targets to achieve track efficiency and effectiveness of a program. In this study, KPI is defined based on the percentage of pupils acquiring all the twelve constructs mentioned above. This KPI was provided in the "Buku Pengoperasian LINUS 2.0" and in the "Panduan Pentadbiran Saringan LINUS 2.0" (KPM, 2011).

Despite the emphasis and measures taken, some children without learning disabilities were still unable to acquire the basic literacy skills of English during their lower primary school level. This affects the KPI to be achieved by the teachers. This problem is a continuing concern to teachers and policy makers alike as every Malaysian child is expected to acquire these skills after 3 years of mainstream primary education (Kementerian Pendidikan Malaysia, 2015).

\section{Literature Review}

A closer look into the recent literature showed that researchers have focused on the evaluation of literacy instruction program for a variety of purposes. In light 
of the LINUS program, some local researchers have conducted research on different aspects related to the implementation LINUS program. However, these studies seemed to focus on the Malay language and numeracy program such as, a study by Evelyn Wong (2014), Nazariyah Sani and Abdul Rahman Idris (2013), and Marina Ramlee (2012).

Wong's (2014) study measured the level of LINUS program management in a Johor primary school. A questionnaire on the management of objectives, communication, supervision and evaluation, curriculum, pupils' achievement, teaching and learning was administered. The findings of the study revealed that the mean and standard deviation for each of the identified dimensions were encouraging. A discussion between teachers and the management was important in reducing the number of LINUS (LBI) pupils.

In another study, Othman, Normarini, Darusalam and Siraj (2011) studied the relationship between implementation of the LINUS program and challenges that the LINUS teachers had to face in attaining the mastery of literacy skills. The findings revealed that having well-planned strategies, coupled with teaching and learning plans from the teachers involved could overcome the obstacles and challenges faced. Although most of the language teachers had a positive attitude towards the subject, it was revealed that they still lack the skills in teaching the program.

Nazariyah Sani and Abdul Rahman Idris (2013) examined school leaders' understanding of the implementation of the LINUS program based on features highlighted by Van Meter and Van Horn (1975). The model was adopted for the implementation of the LINUS program in four Selangor schools. The findings showed that the good understanding of the program's objectives was the major factor in the success of program. Thus, with minor modifications of Van Meter and Van Horn's Program implementation model, it could be useful for the implementation of the LINUS (LBI) 2.0 program in school.

In another study, Marina Ramle (2012) investigated the effect of technical instruction on reading skills performance of the LINUS pupils. A pre-test and post-test using a pattern matching with non-equivalent dependent variable was carried out to identify the effect of the technical instruction: repetition, progression, educate entertaining and technique of intermingling was carried out. The study identified that there was a significant improvement on LINUS pupils' achievement of reading basic skills.

Furthermore, Tubah and Hamid (2011) examined the influence of demography on reading and comprehension skills of LINUS pupils. The study was built on Vygotsky's theories on the role of "scaffolding" and "ZPT". They suggested that these two concepts serve as a guide for the LINUS teachers in teaching reading and comprehension skills in the LINUS class. The study revealed that not all the demographic factors of pupils or teachers seem to influence the pupils' reading and comprehension skills. This demonstrates that the LINUS teachers must be able to determine the pupils' readiness, and are clear about the level or stages of guidance (scaffolding) that needs to be delivered to the LINUS 
pupils. It would be valuable for the LINUS teachers to acquire the psycholinguistic method of teaching, which emphasizes mental ability and mastery of language. This could facilitate the pupils' reading and comprehension skills.

A study by Yamat, Fisher and Rich (2014) focused an ethnographic case study with three aged six primary school pupils. The findings of the study indicated that acquisition of the second Teachers' Perception on the Implementation of the LINUS LBI 2.0 Program language was done through play and use, and began with the pupil's development of confidence at the early stage. The implications of the results are examined in the light of English Language policy for teaching English to Malaysian primary school pupils. The study concluded and implies that changes or interventions should be made early particularly for English Language teaching at primary schools. However, it was identified that only a limited number of research has been conducted on English language literacy among primary school pupils in Malaysia which is relatable to LINUS LBI.

\section{Methodology}

\subsection{Research Design}

For this study, a mixed method research design was chosen. Mixed method research design is the type of research in which a researcher combines elements of qualitative and quantitative approaches for the broad purposes of breadth and depth of understanding and corroboration (Johnson \& Christensen, 2007). This approach to research is used when this integration provides a better understanding of the research problem than either of each alone.

\subsection{Participants}

Purposive sampling was used in this study. The participants were selected based on two criteria. The first criteria in determining the population sample of the study is the schools which have failed in achieving the LBI KPI for the year 2018. Another criterion that was used to select the participants of the study is that they represent Grade B schools. This study was conducted with thirty six Grade B schools in Temerloh District. The teachers who have been teaching English subject for the lower primary pupils were selected as the participants. The schools were located in the rural area of Temerloh district.

\subsection{Data Collection}

This study embraced mixed method approach and thus employed methods that are in line with the study. The research instruments are teacher individual interview and questionnaire. For this study, 5-point Likert scale is used. Likert developed the principles of measuring attitude by asking people to respond to a series of statements. The number of teachers selected an option for a statement, determined if they strongly disagreed, disagreed, not sure of the response, agreed, and strongly agreed to the statement.

As the teacher has a direct involvement with the issue studied, individual in- 
terview was used to gather data from the teacher. The questions were divided into three sections. Section A of the questions required the teacher to reflect on teacher's background information. Section B of the questions focuses on the perception of the teacher on the failure of achieving the LBI KPI. Section C of the questions provides the questions for the teacher to reflect on the possible factors that contributes to the failure in achieving the LBI KPI.

\subsection{Data Analysis}

The quantitative data consisted of results from the questionnaire administered to the teachers. The number of teachers selected an option for a statement. All the data were collected, processed and analyzed using the Statistical Package for the Social Science (SPSS). The data were statistically analyzed using frequency counts and percentage distribution. The percentage distribution was computed to determine if the unavailability of resources and facilities together with lack of training and support has contributed to the failure in the achievement of LBI KPI. The data from interviews were analyzed using Burnard's method (Burnard et al., 2008). Burnard proposes 14 stages in analysing qualitative data. Burnard's method is based on a synthesis between grounded and content analysis approach. This method was used to categorize and code the transcribed interview data. The three themes derived from the responses: 1) Pupils' attendance, 2) Cooperation from stakeholders, and 3) Pedagogical knowledge.

\section{Results and Discussion}

The findings of this study have indicated that the resources and facilities are unavailable in schools. This was in terms of module, activity books, teaching aids, and special facilities. Besides, lack of training and support was also identified. Through the individual interview, it was identified that attendance, cooperation, and pedagogical knowledge were also equally important and contributing factors in this case.

\subsection{Does the Unavailability of Resources and Facilities Contribute to the Failure in the Achievement of LBI KPI in Grade B National Schools in Temerloh District?}

This questionnaire entitled "Resources and Facilities" was administered to all 80 participants based on four subsections. The answers are divided into 4 parts which answers the four subsections; 1) Module and activity books, 2) Instruments, 3) Teaching aids facilities, and 4) Special Facilities.

\subsubsection{Module and Activity Books}

45 Participants with a total rate of $56.2 \%$ strongly agreed that LINUS modules are provided to schools by the Ministry of Education. This resource plays an important role in ensuring pupils achieving the targeted constructs. However, there were no other additional activity books provided to enhance pupils' LBI acquisition. This was agreed by 39 participants with a total rate of $48.7 \%$. The 
number of LINUS modules provided to the schools were also found to be nor equivalent to the number of pupils who did not achieve the constructs. This was supported by 37 participants with a rate of $46.2 \%$. 33 participants with a rate of $41.2 \%$ disagreed that the LINUS modules provided follows the twelve constructs exactly. The content of the module was general and the teachers were required to find the suitable content of the module which matches the construct they intend to teach. Finally, the effectiveness of using the modules in improving the pupils' acquisition of the twelve construct was questioned. For this, 30 participants with a total rate of $37.5 \%$ chose not sure as their response.

\subsubsection{Instruments}

For every writing screening test, the instrument was given by the Ministry to each school based on the number of pupils enrolled. This was strongly agreed by 44 participants with the rate of $55 \%$. The instruments given were also error-free as supported by 36 participants with the rate of $45 \% .38$ participants have agreed that the items in the instruments are apt for the construct given. This means $47.5 \%$ of participants have agreed to this. Besides, coordinators having a wider knowledge about the screening test were also seen as one of the resources. In this case, 47 participants have agreed that the coordinators have a wide range of knowledge about LINUS screening test. This helps those non-optionists in conducting the LINUS LBI screening test. Another resource given was the "Panduan Pentadbiran Saringan".

\subsubsection{Teaching Aids Facilities}

About 34 participants with the rate of $42.5 \%$ disagreed that printers and computers are prepared to print out the screening test instruments. Similarly 25 participants with the rate of $43.7 \%$ disagreed that there were sufficient ICT facilities available at the schools. This has resulted in ICT facilities not being used for LINUS. Even though the government has been equipping the schools with ICT facilities, this scenario is unacceptable. This statement was largely agreed by the participants with the rate of $52.5 \%$. The insufficient ICT facilities in schools even in 4th Industrial Revolution era had to be solved as soon as possible. The use ICT in LINUS had higher potential in improving pupils' acquisition. Utilizing these highly potential tools should give teachers a cutting edge in engaging learners in their lessons which will definitely produce a positive result. Other than ICT facilities, teaching aids facilities were also important. However, 56.2\% of teachers strongly disagreed that the teaching aids were provided. Teachers were needed to plan engaging activities and teaching aids to improve the literacy skills. Norfaizrenah \& Melor (2016) have agreed that instead of doing the activities in stuffed classroom environment, activities done in more relaxing surrounding provide additional support to enable students who have literacy problems in English language. This supported the next statement, where $37.5 \%$ of the participants strongly agreed when asked if the teaching aids were produced on their own. Ahmad and Mutalib (2015) agreed that producing teaching aids 
was time consuming and most of the teachers had to do it all alone. The data from the interview was used to triangulate the data for this section. The time constraint factor had an impact on preparation of teaching aids. The teachers had to settle almost every work besides their core business which was teaching. The time constraint factor has prohibited teachers to come up with teaching aids. Hence, it was proven that teaching aids facilities are not provided and the teachers are needed to be provide with teaching aids.

\subsubsection{Special Facilities}

A large number of participants disagreed that there was a separate room prepared to conduct the LINUS screening test. 37 participants with the rate of $46.2 \%$ disagreed to this. The data from the interview was used to triangulate the data for this section. The cooperation of school administrator's factor was linked to this. Such facilities should be prepared by the school administrators as it helps the teacher to conduct the screening test. The availability of "Guru Pemulihan" is another factor that was studied. It was a known factor that "Guru Pemulihan" helped pupils who did not achieve the KPI in LBM and Numerasi. However, for LBI, "Guru Pemulihan" was not able to guide the pupils. This totally depended on the teachers who teach the subject. Hence, 66 participants have strongly disagreed that "Guru Pemulihan" is available to help with the pupils who did not achieve the KPI. Bokhari et al. (2015) also supported that these English teachers had to double up their effort as remedial teachers as well since there were no assistance for them. Interventions planned were another resource that aided teachers in achieving the targeted constructs and KPI. 53 participants with the rate of $66.2 \%$ disagreed that the screening test is easier to be conducted during teaching and learning session. 39 participants with the rate of $48.7 \%$ disagreed that the interventions are planned right after the screening test. For the following statement, 43 participants with $53.7 \%$ disagreed that interventions helped in overcoming the shortcomings. This is mainly because teachers do not present their intervention ideas usually. Only the headmasters were called for the session.

In short, it can be concluded that the unavailability of resources and facilities are indeed a deciding factor of failure in achieving the LBI KPI. This is because there was not any activity book besides LINUS modules were given to schools. Matimbe (2014) is of the view that lack of instructional materials such as syllabi and textbooks to use during teaching and learning process negatively affects effective teaching. The number of modules given was not equivalent to the number of pupils. Sawchuck (2011) posits that the provision of textbooks at a ratio of either one book per child or one book for every two children make a very significant difference on achievement. Most of the teachers also disagreed that the modules are effective in improving the pupils' acquisition. Secondly, there were not enough ICT facilities to be used in this LINUS course and teachers came up with their own teaching aids which are time consuming. However, the resources provided by the Ministry, which is the Screening Test instrument was provided 
equivalent to the number of pupils and is error-free. The participants also agreed that the coordinators having wide knowledge about the screening test which was helpful for all the teachers. Lastly, the special requirements such as having a separate room for screening, "Guru Pemulihan" to help with the LBI as well were factors to be considered in regards to failure in achieving LBI KPI. This was supported by Adeogun (2001), where he discovered a very strong positive significant relationship between instructional resources and academic performance. Hence, this answers the first research question that unavailability of resources and facilities did contribute to the failure in the achievement of LBI KPI in grade B national schools in Temerloh District.

\subsection{Does Lack of Training and Support Contribute to the Failure in the Achievement of LBI KPI in Grade B National Schools in Temerloh District?}

The questionnaire entitled "Training and Support" was administered to all 80 participants based on three subsections. The answers are divided into 3 parts which answers the three subsections; 1) PPD Facilitators; 2) LINUS coordinators; and 3) Dialog Perlaksanaan Intervensi.

\subsubsection{PPD Facilitators}

Each school was appointed with one or two facilitators to guide the teachers with LINUS screening test and its administration. Before each screening test, a briefing is conducted at the PPD level by the facilitators. However, $42.5 \%$ of participants, which was 34 participants have disagreed that the briefing is conducted to all the lower primary teachers who were involved with the LINUS LBI screening. Only the coordinators or selected teachers were called for the briefing. Yet, the briefing given by the facilitators was precise and clear, which was supported by 40 participants with the rate of $50 \%$. The facilitators have also guided the teachers throughout the screening test. This was particularly done when the facilitators do their monthly visit to the schools. This was agreed by 45 participants with the rate of $56.2 \%$. Nevertheless, the participants have disagreed that the facilitators accept when more than 10 pupils could not achieve the KPI.

\subsubsection{LINUS Coordinators}

It was proved that before each screening test, a briefing is conducted to all the LINUS teachers in schools. This was agreed by 40 participants with the rate of $50 \%$. The briefing given was also precise and clear as agreed by 55 participants with the rate of $68.7 \%$. The role of LINUS coordinator continued throughout the LINUS screening test. The coordinators are said to be giving guidance throughout the screening test period. This statement was agreed by 45 participants with the rate of $56.2 \%$. However, the next statement got different perspective from the participants. Only 28 participants, with the rate of $35 \%$ agreed that the LINUS coordinators accept when there are more than 10 pupils who did not achieve the KPI set by the Ministry. Around 19 participants disagreed to this statement with the rate of $23.7 \%$. Yet, 38 participants with the rate of $47.5 \%$ have agreed that 
coordinators, even though some of them could not accept the actual result, they still helped the teachers in planning the interventions.

\subsubsection{Dialog Perlaksanaan Intervensi}

This Dialog Pelaksanaan Intervensi was important as the headmasters of each school had to present the intervention carried out in schools to the Head of PPD. This was agreed by most of the participants which was 59 participants where they opted for agreed to this statement. However, the effectiveness of this program is still a big question. 21 participants with the rate of $26.2 \%$ and 20 participants with the rate of $25 \%$ have simultaneously chosen disagree and strongly disagree to the statement. This might have been because, the interventions were not presented by the teachers but the Headmasters. 56 participants with the rate of $70 \%$ strongly disagreed that the presentation was done by the teachers. Similarly, 33 participants with the rate of $41.2 \%$ disagreed that this program helps teachers to get more ideas on planning intervention. This was mainly because the intervention sharing session was done with the headmasters and not the teachers. Following that, 35 participants with the rate of $43.7 \%$ disagreed that the Dialog Pelaksanaan Intervensi helps them in finding the suitable material to be used in intervention. The data from the interview was used to triangulate the data for this section. Teachers' pedagogical knowledge too influence and had a great impact on the selection of materials for non-achievers. Some of the teachers agreed that they needed pedagogical knowledge as they are teaching small kids.

In short, it can be concluded that lack of training and support is identified among teachers in grade B national schools in Temerloh District. Owoko (2009), the term resources refers not only to teaching methods and materials but also the time available for instruction, the knowledge and skills of teachers acquired through training and experience. PPD facilitators have been guiding the teachers throughout the screening test period whenever they visited the schools. Yet, there is a need to conduct briefing for all the teachers who are involved with LINUS LBI screening test as this would be a great platform for them to clear their doubts. Facilitators' unwillingness to accept the result of LINUS LBI screening test was also a factor. This made the teachers to come up with different ideas to enhance pupils' acquisition. However, there was not any training given for teachers to come up with interventions to solve the shortcomings. This was agreed by Lyons (2012) learning is a complex activity that involves skills of teaching and curriculum demands. Teachers should be able to plan lessons effectively. Even though, coordinator has helped the teachers in planning interventions, a formal training and support was needed. This was agreed by most of the participants. The Dialog Pelaksanaan Intervensi was carried out, but the content was not presented by the teachers. It was difficult for the teachers to find a suitable material or content to be used with the pupils. Hence this answers the second research question, where it was agreed that the lack of training and support did contribute to the failure in the achievement of LBI KPI in the grade B national 
schools in Temerloh district. Following this, other contributing factors to this issue were also identified through interview.

\subsection{What Are the Other Contributing Factors to the Failure in the Achievement of LBI KPI in Grade B National Schools in Temerloh District?}

This interview was administered to all 80 participants. There were 54 optionists and 26 non-optionists. Most of the participants had at least five years of teaching experience. The rest of them were senior teachers who had ten to fifteen years of teaching English experience. They have been administering the LINUS LBI screening test for the past five years. Almost all of them answered and agreed that the LBI KPI is the most difficult to achieve as it was the second language of the pupils. The answers for the open ended questions were divided into three parts which answers the three themes; 1) Attendance; 2) Cooperation, and 3) Pedagogical knowledge.

\subsubsection{Attendance}

Most of the participants were expressing that pupils' attendance had a great impact on the failure in the achievement of LBI KPI in grade B national schools in Temerloh district. This statement is derived from the teacher's interview responses. Wadesango \& Machingambi (2011) states that, students who have absenteeism problems are at higher risk of poor performance. The participants have confessed that they faced a serious problem when it comes to pupils' attendance. Their attitude determines the achievement of the KPI. Even though a few measures were taken, there were not any changes in the pupils' attendance. Out of 36 schools, almost 15 schools had this problem.

A lot of intervention programs especially to attract pupils' attention and make them interested in going to school were carried out. For example, giving out free food coupon, star badges, RM 1 per day, 30 minutes play-time and so on. The findings also support the findings of other researches that Malaysian students are more extrinsically motivated than intrinsically motivated (Zubairi \& Sarudin, 2009). Some schools had meetings with the parents, Parents Teachers Association members and representatives to come up with a solution for this problem. However, some pupils were still not interested in going to schools. Their negative attitude has a great impact on this issue. This was supported by Asraf and Ahmad (2003), as they found that negative attitudes lead to class anxiety, low cognitive achievement, and low motivation. The Participants added that this issue was discussed in all levels, especially in school meetings, PPD meetings and LINUS meetings. Yet, there was not any definite solution that solved this problem. The blame was still on the teachers.

Pupils' attendance has a great impact on the achievement of LBI KPI. The consequences of poor attendance can be far reaching. Neill (1979) found that lack of school attendance could lead to permanent intellectual damage to students, as gaps in students' knowledge bases would be likely to arise. Even though 
the rest of the pupils achieve all the twelve constructs, the attendance problems of some pupils could still result in the failure of LBI KPI achievement. This happened mostly in Year 2 and Year 3 classes. The pupils were needed to master all twelve constructs by the end of Year 3. The failure of the achievements resulted in headmasters of the schools being called to the PPD.

\subsubsection{Cooperation}

Parents too, should play active role in encouraging their children to do well in the language (Siti \& Melor, 2014). The parents' cooperation was beneficial and influential to the overall success of the school (Cotton \& Wikelund, 2001). This goal could further be achieved when the parents participates fully in their children's educational process by attending their children's school functions such as attending Parent Teacher's Association's (PTA) meetings. First, it was mentioned that some parents care less about the pupils' achievement. They believed that pupils' academic achievement relies solely on teachers. Even when the pupils fail to acquire the skills, the teachers were to be blamed. It was also revealed that, when the school authorities had meetings to clarify issues and find solutions to problems like attendance, academic achievement and moral issue, these parents sometimes, would not attend the meetings. Even when they attend, they do not care about the pupils' progress. Second cooperation scenario that happened with the parents was they do not accept the pupils' progress as it is. When the pupils were asked to stay for intervention classes due to their poor achievement in LBI, the parents were in a great shock. Only then, they realized that their children's progress needs to be improved. However, they went and blame the teachers for it. This happened in most of the schools. It was revealed that the parents' have some issues with their children attending the intervention classes when the other children do not have to.

The school administrations as the education stakeholders too were the contributing factors of this issue. The cooperation issue with the schools administrators was sometimes they had difficulty in understanding the real issue. The teachers were putting so much effort into LINUS issue. So many interventions were planned and carried out. There were still some pupils who did not make any progress. Yet, the school administrators had difficulty in understanding this and they kept on pushing the teachers to come up different plans to solve this issue. Some administrators too had problem when the teachers could not achieve the KPI set by the Ministry. Every school that faced this scenario had to attend the Dialog Pelaksanaan Intervensi. In order to avoid this, there was so much pressure on the teachers. The data from the questionnaire was used to triangulate the data for this section. The data from the questionnaire revealed that there were special requirements such as availability of separate room to conduct the screening test. However, there was not enough cooperation from the school administrators in preparing the special requirements needed for the screening test.

\subsubsection{Pedagogical Knowledge}

Another contributing factor to this failure in the achievement of LBI KPI is be- 
ing an optionist and a non-optionist. In this study, there were 54 optionists and 26 non-optionists. All of them faced equal problems in this matter. Mavhunditse (2014) is of the view that experience is one of the major factors contributing towards effective teaching. However, being a TESL optionist also had its own disadvantages. The participants have felt that having enough pedagogical knowledge was not just enough to come up with solution for not being able to achieve the LBI KPI. They added that being trained for five and a half years was not enough. The optionists were planning interventions, executing it, using variety of teaching methods to make the pupils acquire certain literacy elements with the pedagogical knowledge that they had. However, a fruitful result could not be obtained. The participants have also expressed that the expectations with the optionists were quite high. They were expected to come up with alternatives all the time whenever an issue was raised regarding their major.

Being a non-optionist too was a contributing factor to this issue. 26 participants out of 80 participants of this study were non-optionists. This is an important factor as the success of a programme would largely depend on the practitioners of the programme (Van Meter \& Van Horn, 1975). Shulman (1986), for example, introduced three dimensions for teacher knowledge base that include subject matter content knowledge, pedagogical content knowledge, and curricular knowledge. In this study subject matter knowledge and pedagogical content was lacking among the non-optionist. They expressed that they were lack of pedagogical knowledge in teaching English. Even though most of them had a teaching experience of five years, yet not having the pedagogical knowledge did contribute to this issue. They had degree in different major. But, insufficient English teachers in school were a major issue so they were given the responsibility to teach English Language. These participants agreed that it was tiring to come up with different solutions for the failure in the achievement of LBI KPI. There was a lot of pressure on them. However, they put so much effort into this to make sure the pupils excel. They expressed that they survived all this while with the guidance from the senior teachers and the sharing session among their friends. Thus, this calls for skilled and trained English Language teachers with the imposition of language proficiency. This should make as a prerequisite (Azman, 2016).

Thus, this section identified the other contributing factors which answered the third research question and that it is important to be considered by the Ministry of Education in implementing a program. A careful look into these issues determines if the LBI KPPI could or could not be achieved.

\section{Implication}

A program's success has implications on its stakeholders. Malaysian Education system aimed to produce pupils who are developed holistically and acquire all skills to be globally competent. This is in line with the National Education Philosophy and the New Education Blueprint (2013-2025). In order to be globally 
competitive, one has to master all the skills. The mastery of skills begins as early as the pupils enter the preschool and it begins with mastery of literacy skills.

Numerous measures were taken by the Ministry to enable the pupils to master the literacy skills. One of them was the LINUS screening test especially LBI which related to shift 2 in NEB. However, there were so many factors that resulted in the failure of achievement of LBI KPI. This research identified the possible factors the teachers have faced in achieving the LBI KPI. This had made the teachers aware of the individual needs of the pupils. This will help them in identifying the learning style and the suitable material to be used with each pupil in order to acquire the construct.

This research also gave a new look into this problem. The teachers were blamed for the failure in the achievement of the LBI KPI all this while. Yet, the real reasons were identified through this research. This research would be a great help in getting cooperation from the parents, pupils, school administration and the Ministry itself. Besides that, teachers were also in need of training and support. After 5 years of LBI implementation, one of the reasons for the failure in the achievement of LBI KPI was training and support. This was because there was lack of pedagogical knowledge among the non-optionists. Through this research, the Ministry could provide more training and support to these teachers in order to achieve the KPI set by the Ministry.

Through this research, the Ministry of Education will be aware of the factors faced by the teachers which contribute to the issue which will make ways for implementation of new plans and programs that ease teacher's work. It is expected for Ministry to equip teachers with the training, support, facilities and resources which help teachers to improve their teaching method so that it can help learners to acquire the basic literacy skill, especially English Language Literacy skills.

\section{Recommendation}

The following are some suggestions that researchers might want to consider for future research. First, this study can be further explored by identifying factors that makes KPI of Malay Language and Numerasi achievable. This could also be explored in terms of cooperation, facilities and support the teachers have been getting which enable them to achieve the LBI KPI. Second, multiple researches can be carried out to compare the outcomes of the findings. Future researchers can choose schools with homogeneous or different characteristics. This study only focused on grade B national schools in Temerloh district. Studies can be done by comparing different types of schools or schools from different districts and states.

Third, knowledge on pedagogy should allow teachers to manipulate all the teaching method for teaching and learning purposes. Therefore, it is also important to study the teachers' pedagogical knowledge in administering LINUS screening. Preparing in-training teachers for the real classroom is also crucial to meet the challenges of teaching English as non-optionists. In this way, the 
non-optionists will be equipped with the knowledge on how to overcome that raises in ESL classroom. Finally, this study could also be expanded on areas of suggestions for improvisation of LINUS LBI screening test administration. This study has only focused on the factors of the failure that the teachers were facing. Yet, the suggestion for improvisation was not explored. This could help the other teachers to know which method or approach to be used in tackling the factors. Therefore, future researchers could look into this need.

\section{Conclusion}

This research was conducted to investigate teacher's perceptions on failure in achieving LBI KPI in grade B national schools in Temerloh District. The findings of the study indicated that the unavailability of resources and facilities and lack of training and support contributed to the failure in the achievement of LBI KPI. Teachers too shared the other contributing factors they faced in achieving the LBI KPI through the interview.

All these factors have contributed to the failure in the achievement of LBI KPI. This can be seen from the questionnaire data and interview data. More resources and facilities together with training and support should be provided. Pupils' attendance, cooperation of the stakeholders and pedagogical knowledge had a higher influence on the issue. In this 4th Industrial Revolution, soft skills are given importance. The basic of soft skills largely depends on the literacy skills. Hence, acquiring the literacy skills, especially English Language is compulsory. In order to achieve the LBI KPI, the factors contributing to this issue should be studied in detail. This benefits most of the stakeholders.

\section{Conflicts of Interest}

The authors declare no conflicts of interest regarding the publication of this paper.

\section{References}

Adeogun, A. A. (2001). The Principal and the Financial Management of Public Secondary Schools in Osun State. Journal of Educational System and Development, 5, 1-10.

Ahmad, S. Z., \& Mutalib, A. A. (2015). Preliminary Study: An Investigation on Learning Assistance Requirement among Low Achievers in Primary Schools. International Journal of Computer Applications, 114, 48-54.

Asraf, R. M., \& Ahmad, I. S. (2003). Promoting English Language Development and the Reading Habit among Students in Rural Schools through the Guided Extensive Reading Program. Reading in a Foreign Language, 15, 83-102.

Azman, H. (2016). Implementation and Challenges of English Language Education Reform in Malaysian Primary Classrooms. 3L: The Southeast Asian Journal of English Language Studies, 22, 65-78. https://doi.org/10.17576/3L-2016-2203-05

Bokhari, R., Rashid, S. M., \& Chan, S. H. (2015). Teachers' Perception on the Implementation of the Literacy, Numeracy and Screening (LINUS LBI 2.0) Programme among Lower Primary ESL Pupils. Malaysian Journal of ELT Research, 11, 108-121.

Burnard, P., Gill, P., Stewart, K., Treasure, E., \& Chadwick, B. (2008). Analysing and Pre- 
senting Qualitative Data. British Dental Journal, 204, 429-432.

https://doi.org/10.1038/sj.bdj.2008.292

Cotton, K., \& Wikelund, K. R. (2001). Parent Involvement in Education.

https://educationnorthwest.org/sites/default/files/parent-involvement-in-education.pdf

Johnson, B. R., \& Christensen, L. B. (2007). Educational Research: Quantitative, Qualitative, and Mixed Approaches. Los Angeles, CA: SAGE.

Kementerian Pendidikan Malaysia (KPM) (2011). Bukupanduandanpengoperasian: Program literasidan numerasi (LINUS). Kuala Lumpur: Bahagian Pembangunan Kurikulum Kementerian Pendidikan Malaysia.

Kementerian Pendidikan Malaysia (KPM) (2015). Pelan Pembangunan Pendidikan Malaysia 2013-2025.

Lyons (2012). Do School Facilities Really Impact a Child's Education. An Introduction to the Issues. http://sdpl.coe.uga.edu/articlesandpapers/lyons.html

Matimbe (2014). Financial Management. Harare: Zimbabwe Open University.

Mavhunditse, T. (2014). Legal Perspectives in Education. Harare: Zimbabwe Open University.

Neill, S. (1979). Keeping Students in School: Problems and Solutions. AASA Critical Issues Report. ERIC Document Reproduction Service No. ED 177704, Arlington, VA: American Association of School Administrators.

Norfaizrenah, A. M. S., \& Melor, M. Y. (2016). Improving Pupil's Achievement in Linus 2.0 Using Sound with Me Program. In e-Proceedings of the International Conference on Education (pp. 545-549).

Othman, A. J., Normarini, N., Darusalam, G., \& Siraj, S. (2011). Cabaran Guru Program Linus Dalam Pengajaran Dan Pembelajaran Bahasa. Issues in Education, 34, 37-51.

Owoko, I. S. (2009). The Role of Advocacy in Enhancing Equalization of Opportunities for Disabled People, Presented in Leonard Cheshire Disability Workshop in Kisumu.

Rahman, N. H. (2014). From Curriculum Reform to Classroom Practice: An Evaluation of the English Primary Curriculum in Malaysia. White Rose.

Ramle, M. (2012). Kesanteknikpengajaranterhadapprestasikemahiranmembaca murid permulihan LINUS. Faculty of Education Studies, University Putra Malaysia.

Sani, N., \& Idris, A. R. (2013). Implementation of Linus Programme Based on the Model of Van Meter and Van Horn. The Malaysian Online Journal of Educational Science, 1, 25-36.

Sawchuck, S. (2011). EWA Research Brief Studies Say about Teacher Effectiveness. London: Sage Books.

Shulman, L. S. (1986). Those Who Understand: Knowledge Growth in Teaching. Educational Researcher, 15, 4-14. https://doi.org/10.3102/0013189X015002004

Siti, S. C. M., \& Melor, M. Y. (2014). Attitudes and Motivation towards Learning English among FELDA School Students. Australian Journal of Basic and Applied Sciences, 8, $1-8$.

Thirusanku, \& Melor, M. Y. (2014). Public Examinations in Malaysia. Asian Social Science, 254-260.

Tubah, H., \& Hamid, Z. (2011). Pengaruhdemografiterhadapkemahiranmembacadan memahamidalamkalangan murid-murid LINUS. Jurnal Melayu, 6, 29-47.

UNESCO Education Position Paper. (2004). The Plurality of Literacy and the Implications of Its Policies and Programs, p. 13.

http://unesdoc.unesco.orgimages/0013/001362/136246e.pdf 
Van Meter, D. S., \& Van Horn, C. E. (1975). The Policy Implementation Process: A Conceptual Framework. Administration \& Society, 6, 445-488. https://doi.org/10.1177/009539977500600404

Wadesango, N., \& Machingambi, S. (2011). Causes and Structural Effects of Student Absenteeism: A Case Study of Three South African Universities. Journal of Social Sciences, 26, 89-97.

Wong, E. (2014). Amalan LINUS sekolah kebangsaan zon Parit Bunga, Daerah Muar. Faculty of Education, University of Technology Malaysia.

Yamat, H., Fisher, R., \& Rich, S. (2014). Revisiting English Language Learning among Malaysian Children. Asian Social Science, 10, 174-180. https://doi.org/10.5539/ass.v10n3p174

Zubairi, A. M., \& Sarudin, I. H. (2009). Motivation to Learn a Foreign Language in Malaysia. GEMA Online Journal of Language Studies, 9, 73-87. 